\title{
Analysis of mean transcutaneous capnography in consecutive patients undergoing polysomnography
}

Análise da capnografia transcutânea média em indivíduos consecutivamente submetidos à polissonografia

Giulio Cesare Pinnola, Patrícia Souza Bastos

\begin{abstract}
Transcutaneous capnography is a noninvasive method useful for analysis of the behavioral tendency of transcutaneous $\mathrm{CO}_{2}$ pressure $\left(\mathrm{PtcCO}_{2}\right)$ in patients undergoing polysomnography, to evaluate respiratory sleep disorders. Objective: Determine normative $\mathrm{PtcCO}_{2}$ values in normal patients undergoing polysomnography. Method: One hundred seventy-nine patients who underwent polysomnography with simultaneous $\mathrm{PtcCO}_{2}$ measurement were assessed by means of a transcutaneous capnograph (TCM4 series from Radiomiter). Results: The group classified as normal ( $\mathrm{N}=53$ ) presented a apnea/hypopnea index $(\mathrm{AHI})<5$ events/per hour of sleep and their age groups varied between 7 and 76 years of age. Conclusion: Global mean values of $\mathrm{PtcCO}_{2}$ in the normal group had a Gaussian distribution that varied between 33.1 and $50.0 \mathrm{mmHg}$ (SD 4,363). Such findings allowed the establishment of normative PtcCO 2 values for normal individuals.
\end{abstract}

Keywords: polysomonography, transcutaneous capnography, $\mathrm{CO}_{2}$ pressure.

\section{RESUMO}

A capnografia transcutânea é um método não invasivo útil para análise da tendência comportamental da pressão de $\mathrm{CO}_{2}$ transcutânea $\left(\mathrm{PtcCO}_{2}\right)^{1,2,3} \mathrm{em}$ pacientes submetidos à polissonografia para análise de transtornos respiratórios do sono. Objetivo: Determinar valores normativos da $\mathrm{PtcCO}_{2}$ em pacientes normais submetidos à polissonografia. Método: Foram analisados 179 pacientes submetidos à polissonografia com medida concomitante da $\mathrm{PtcCO}_{2}$ através de um capnógrafo transcutâneo. Resultados: 0 grupo classificado como normal ( $N=53$ ) apresentou índice de apnéia/hipopnéia $(A l H)<5$ eventos/hora de sono e faixa etária variando de 7 a 76 anos. Conclusão: Os valores da média global da $\mathrm{PtcCO}_{2}$ no grupo normal apresentaram distribuição gaussiana variando de 33,1 a 50,0 mmHg (DP 4.363). Tais achados permitiram a criação de valores normativos da $\mathrm{PtcCO}_{2}$ para indivíduos normais.

Palavras-chave: polissonografia, capnografia transcutânea, pressão de $\mathrm{CO}_{2}$.

Transcutaneous capnography is a noninvasive method for analysis of blood gases. It is a useful measuring instrument when it is necessary to know the behavioral tendency of arterial gases ${ }^{1,2,3}$. During the polysomnographic (PSG) examination, carbon dioxide tension $\left(\mathrm{PCO}_{2}\right)$ and oxygen saturation $\left(\mathrm{SatO}_{2}\right)$ are important measurements for characterization of respiratory events related to sleep ${ }^{4}$. Hypoventilating patients tend to retain carbon dioxide $\left(\mathrm{CO}_{2}\right)$ and noninvasive devices that are able to detect alterations during continuous monitoring constitute tools of clinical interest ${ }^{5}$. In order for this measuring method to have credibility, good accuracy, reliable concordance limits regarding arterial carbon dioxide tension $\left(\mathrm{PaCO}_{2}\right)$ and linear variation tendency are necessary $2,6,7$.
Although the measurement of $\mathrm{PaCO}_{2}$ is considered the most reliable direct measurement parameter, it is an invasive method with punctual analysis of the mentioned parameter, which is not sensitive to behavioral tendencies of gas exchanges over time ${ }^{3,4}$.

Nowadays devices for transcutaneous analysis of $\mathrm{CO}_{2}$ present greater stability when registering longer periods ${ }^{2,4,7}$. The differences between the values registered by each device for $\mathrm{PaCO}_{2}$ and $\mathrm{PtcCO}_{2}$ are already known and values up to $\pm 7.5 \mathrm{mmHg}$ are acceptable for radiometer devices. Such differences tend to remain constant during data capture ${ }^{8,9}$. In addition, cutaneous arterialization processes were found to be safe at temperatures up to $44^{\circ} \mathrm{C}$, allowing the electrode 
to remain in contact with the patient for a longer period of time without damages ${ }^{5,10}$. These improvements have contributed to increase reliability and safety of the method ${ }^{1}$.

The objective of this study was to establish normative values for $\mathrm{PtcCO}_{2}$ during the polysomnographic recording in patients whose age group varied from 7 to 76 years old, defined as normal.

\section{METHOD}

The study was accepted by the research ethics institutional committee at Sarah Network Hospital. One hundred seventynine patients underwent polysomnography with simultaneous recording of transcutaneous capnography, in the period between January 2010 and August 2012, consecutively. The normal group ( $\mathrm{N}=53$ ) was the object of our study. The patients classified as normal presented an apnea/hypopnea index (AHI) $<5$ events/per hour of sleep. The patients underwent PSG with the most varied objectives. The American Sleep Academy Manual of 2007 was used for sleep staging and associated events ${ }^{11}$. By means of assessment of digital clinical records it was possible to exclude those patients with respiratory co-morbidities, positive history of smoking, presence of neuromuscular diseases and ischemic or compressive lesions of the brain stem.

Abnormally high values due to calibration problems of the device or abnormally low due to poor fixation of the electrode, presence of air bubbles and a wide range of oscillation of $\mathrm{PtcCO}_{2}$ values caused by motion artifacts were reasons for not including some of the patients in the normal group.

The TCM4 series device from Radiometer was used to analyse patient's transcutaneous capinography. The $\mathrm{PtcCO}_{2}$ electrode was placed in the second right intercostal space during the entire recording and a $42^{\circ} \mathrm{C}$ temperature was maintained. Biocalibration of the device was done while the patient was still awake and not repeated during the night, except if abrupt alterations of recorded values were noticed.

Capillary blood gasometry was carried out with the objective of validating the transcutaneous capnography method. Analysis of the capillary blood sample was the method of choice for validation of transcutaneous capnography because it is a less painful method than arterial gasometry and technically easier to perform. Sample collection occurred before the beginning of PSG, when the patient was at rest and awake. Blood sample was obtained from the ear lobe, as it is a region with more arterialization when compared to the digital pulp.

\section{RESULTS}

The mean transcutaneous capnography $\mathrm{CO}_{2}$ rate of each patient was analyzed during the polysomnographic recording.

Table. Mean and standard deviation of age and mean transcutaneous carbon dioxide pressure (PtcCO2) in the normal group $(\mathrm{N}=53)$.

\begin{tabular}{|c|c|c|c|c|}
\hline & & & Statistics & Standard error \\
\hline \multirow[t]{13}{*}{ Age } & Mean & & 43.13 & 2.261 \\
\hline & 95\% Confidence interval for mean & Lower bound & 38.59 & \\
\hline & & Upper bound & 47.67 & \\
\hline & $5 \%$ Trimmed mean & & 43.49 & \\
\hline & Median & & 46.00 & \\
\hline & Variance & & 270.963 & \\
\hline & Standard deviation & & 16.461 & \\
\hline & Minimum & & 7 & \\
\hline & Maximum & & 76 & \\
\hline & Range & & 69 & \\
\hline & Interquartile range & & 21 & \\
\hline & Skewness & & -.472 & .327 \\
\hline & Kurtosis & & -.464 & .644 \\
\hline \multirow[t]{13}{*}{ Global Mean PtcCO2 (mmHg) } & Global mean & & 41.325 & .5993 \\
\hline & $95 \%$ Confidence interval for mean & Lower bound & 40.122 & \\
\hline & & Upper bound & 42.527 & \\
\hline & $5 \%$ Trimmed mean & & 41.339 & \\
\hline & Median & & 41.400 & \\
\hline & Variance & & 19.036 & \\
\hline & Standard deviation & & 4.3630 & \\
\hline & Minimum & & 32.4 & \\
\hline & Maximum & & 49.5 & \\
\hline & Range & & 17.1 & \\
\hline & Interquartile range & & 7.0 & \\
\hline & Skewness & & -.044 & .327 \\
\hline & Kurtosis & & -.872 & .644 \\
\hline
\end{tabular}




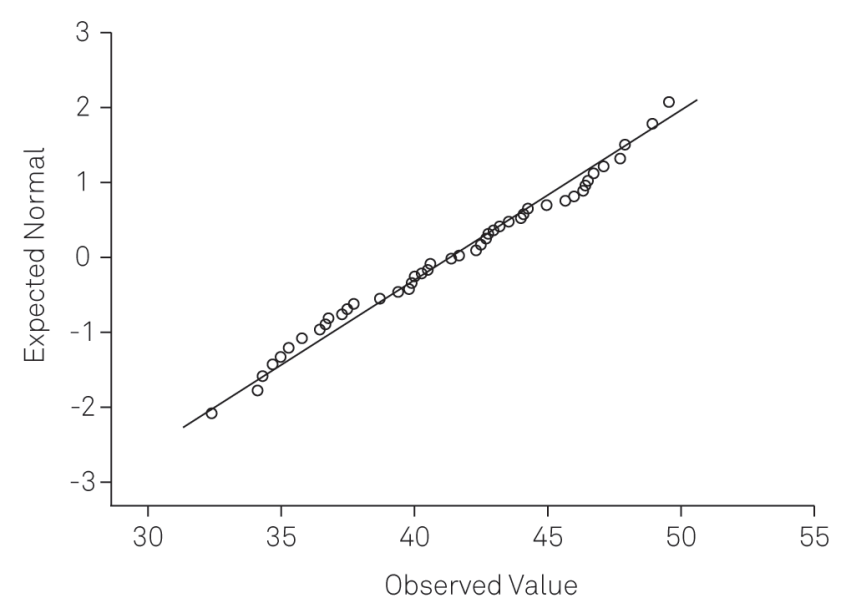

Figure 1. Normal distribution values for global mean transcutaneous carbon dioxide pressure (PtcCO2) in the normal group. Standard deviation of $\pm 2 \sigma$.

Subsequently the mean $\mathrm{CO}_{2}$ rate (called global mean) was assessed using the already calculated $\mathrm{n}$ (the sum of transcutaneous capnography from each patient). Such values were evaluated by means of the Shapiro-Wilk test with Lilliefors significance correction (sig.0.379) for analysis of data normality (Table and Figure 1).

The behavioral tendency of $\mathrm{PtcCO}_{2}$ mean for each individual was observed overnight with the objective of excluding discrepant physiological $\mathrm{PCO}_{2}$ values. Therefore, the individual $\mathrm{PtCO}_{2}$ mean rate would tend to better reflect variations of gas exchanges at the lung level.

The transcutaneous $\mathrm{PtcCO}_{2}$ of each patient was compared to the values obtained from capillary gasometry, which were invalidated and discarded in the $\mathrm{PtcCO}_{2}$ study if the difference between the values were $\pm 7.5 \mathrm{mmHg}^{8,9}$.

In the normal group ( $\mathrm{N}=53)$, the age group varied from 7 to 76 years (mean 43.13 and standard deviation (SD) 16.46), 32 subjects were female and 21 were male. Global mean value of mean $\mathrm{PtcCO}_{2}$ was 41,325 (confidence interval 95\% per mean, varying from 40,122 to 42,527$)$. Standard deviation was 4,363 and $2 \sigma$ was used for calculation of standard deviation, considering as normality interval values $>33.0$ and $\leq 50.0 \mathrm{mmHg}$ (Table and Figure 2).

Global mean values of mean $\mathrm{PtcCO}_{2}$ of normal patients presented a behavior with Gaussian distribution. Variability of $\mathrm{PtcCO}_{2}$ during the exam presented a linear pattern, allowing an estimation of the behavioral tendency of transcutaneous $\mathrm{CO}_{2}$ during PSG in normal patients. Based on this tendency, it was possible to establish normative values of $\mathrm{PtcCO}_{2}$ for the normal patients group.

Due to technical difficulties, the capillary blood sample was carried out in only 23 patients; however, the variation curve of $\mathrm{PtcCO}_{2}$ values was similar to that of patients with

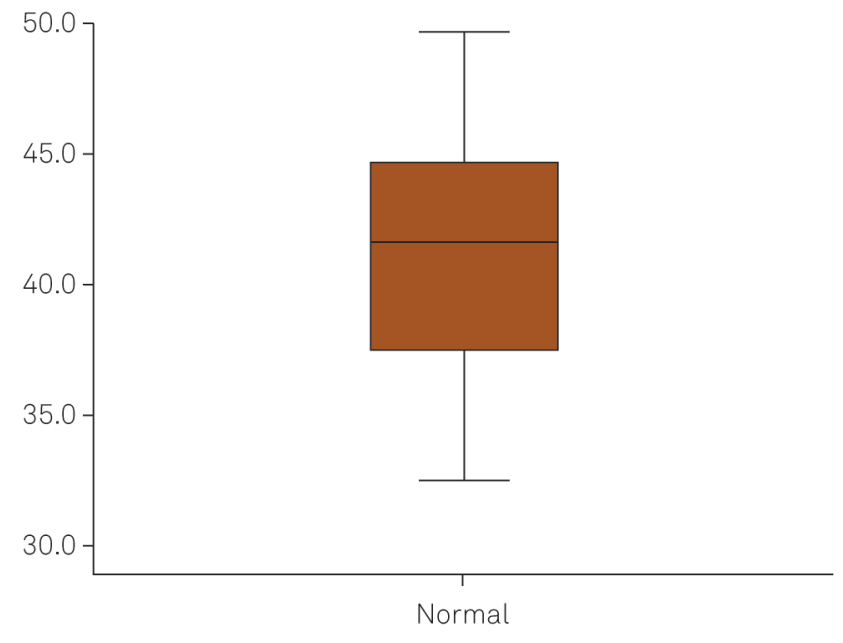

Figure 2. Global mean transcutaneous carbon dioxide pressure (PtcCO2)distribution in the normal group. Values ranging from 33.1 to $50.0 \mathrm{mmHg}$.

a validated transcutaneous technique. Such similarity of behavior was confirmed through ANOVA (sigma between groups 0.615 and F 0.256).

\section{DISCUSSION}

The study did not attempt to assess or even correct the existence of "drift", since the focus of analysis was the mean $\mathrm{PtcCO}_{2}$ and not $\mathrm{PtcCO}_{2}$ in punctual analysis during the night.

These results allow us to conclude that transcutaneous capnography is a noninvasive and totally reliable method. Zavorsky and Yildizdas et all demonstrated that there is no significant variation regarding capillary and arterial $\mathrm{PaCO}_{2}$, when the capillary blood sample is properly arterialized $^{12}$. The behavioral similarity between capillary gasometry and transcutaneous capnography in normal individuals leads us to discard the need to perform capillary gasometry as validation method of transcutaneous capnography.

Further studies in patient with respiratory sleep disorders such as apnea and hypoventilation (obesity/hypoventilation/ neuromuscular diseases syndrome) may be carried out with the objective of identifying mean $\mathrm{PtcCO}_{2}$ abnormality patterns during polysomnographic recording ${ }^{13,14}$.

\section{Acknowledgement}

The authors are indebted to Sandro Barbosa de Oliveira for your untiring assistance in the preparation of this manuscript as a statistician. 
1. Storre JH, Magnet FS, Dreher M, Windisch W. Transcutaneous monitoring as a replacement for arterial $P C_{2}$ monitoring during nocturnal non-invasive ventilation. Respir Med. 2011;105(1):143-50. http://dx.doi.org/10.1016/j.rmed.2010.10.007

2. Hazenberg A, Zijlstra JG, Kertjens HAM, Wijkstra PJ. Validation of a transcutaneous $\mathrm{CO}_{2}$ monitor in adult patients with chronic respiratory failure. Respiration. 2011;81(3):242-6. http://dx.doi.org/10.1159/ 000323074

3. Bland JM, Altman DG. Statistical methods for assessing agreement between two methods of clinical measurement. Lancet. 1986;327(8476):307-10. http://dx.doi.org/10.1016/S0140-6736(86) 90837-8

4. Zavorsky GS, Cao J, Mayo NE, Gabbay R, Murias JM. Arterial versus capillary blood gases: a meta-analysis. Respir Physiol Neurobiol. 2007;155(3):268-79. http://dx.doi.org/10.1016/j.resp.2006.07.002

5. Herrejón A, Inchaurraga I, Palop J, Ponce S, Peris R, Terrádez M et al. Usefulness of transcutaneous carbon dioxide pressure monitoring to measure blood gases in adults hospitalized for respiratory disease. Arch Broncopneumol. 2006;42(5):225-9. http://dx.doi.org/10.1016/ S1579-2129(06)60450-3

6. Berlowitz DJ, Song J, O’Donoghue FJ, Pierce RJ, Brown DJ, Campbell DA et al. Transcutaneous measurement of carbon dioxide tension during extended monitoring: evaluation of accuracy and stability and an algorithm for correcting calibration drift. Respiratory Care. 2011;56(4):242-6. http://dx.doi.org/10.4187/respcare.00454

7. Janssens JP, Perrin E, Bennani I, Muralt B, Titelion V, Picaud C. Is continuous transcutaneous monitoring of $P \mathrm{CO}_{2}\left(\mathrm{TCP} \mathrm{CO}_{2}\right)$ over $8 \mathrm{~h}$ reliable in adults? Respir Med. 2001;95(5):331-5. http://dx.doi.org/ 10.1053/rmed.2001.1045

8. Bollinger D, Steiner LA, Kasper J, Aziz OA, Filipovic M, Seeberger MD. The accuracy of non-invasive carbon dioxide monitoring: a clinical evaluation of two transcutaneous systems. Anesthesia. 2007;62(4):394-9. http://dx.doi.org/10.1111/j.1365-2044.2007.04987.x

9. Bendjelid K, Schüts N, Stotz M, Gerard I, Suter PM, Romand J-A. Transcutaneous Pco2 monitoring in critically ill adults: clinical evaluation of a new sensor. Crit Care Med. 2005;33(10):2203-6. http://dx.doi.org/10.1097/01.CCM.0000181734.26070.26

10. Rodriguez P, Lellouche F, Aboab J, Boisson CB, Brochard L. Transcutaneous arterial carbon dioxide pressure monitoring in critically ill adult patients. Intens Care Med. 2006;32(2):309-12. http://dx.doi.org/10.1007/s00134-005-0006-4

11. American Academy of Sleep Medicine. International classification of sleep disorders: diagnostic \& coding manual. 2nd ed. Westchester: American Academy of Sleep Medicine; 2005.

12. Yildizdas D, Yapicioglu $H$, Yilmaz H, Sertdemir Y. Correlation of simultaneously obtained capillary, venous and arterial blood gases of patients in a paediatric intensive care unit. Arch Dis Child. 2004;89(2):176-80. 10.1136/adc.2002.016261

13. Maniscalpo M, Zedda A, Faraone S, Carratù P, Sofia M. Evaluation of a transcutaneous carbon dioxide monitor in severe obesity. Intensive Care Med. 2008;34(7):1340-4. http://dx.doi.org/10.1007/s00134-008-1078-8

14. Midgren B, Hansson L. Changes in transcutaneous PCO2 with sleep in normal subjects and in patients with chronic respiratory diseases. Eur J Respir Dis. 1987;71(5):388-94. 